\title{
The IGF pathway is activated in insulinomas but downregulated in metastatic disease
}

\author{
Mieke E R Henfling', Aurel A Perren², Anja M Schmitt², Christiane M Saddig³, Achim A Starke³, Robert G Riedl4,*, \\ Yvonne M H Versleijen-Jonkers5, Diana M Sprij-Mooij6, Frans C S Ramaekers', Leo J Hofland 6 and \\ Ernst-Jan M Speel4
}

1Department of Molecular Cell Biology, GROW-School for Oncology \& Developmental Biology, Maastricht University, Maastricht, The Netherlands ${ }^{2}$ Institute of Pathology, University of Bern, Bern, Switzerland

IInsulinoma and GEP-Tumor Center Neuss-Düsseldorf, Klinik für Endokrine Chirurgie, Lukaskrankenhaus Neuss, Germany

4Department of Pathology, GROW-School for Oncology \& Developmental Biology, Maastricht University Medical Centre, Maastricht, The Netherlands ${ }_{5}^{5}$ Department of Medical Oncology, Radboud University Medical Centre, Nijmegen, The Netherlands

${ }^{6}$ Division of Endocrinology, Department of Internal Medicine, Erasmus MC, University Medical Center Rotterdam, Rotterdam, The Netherlands

Correspondence should be addressed to E-J M Speel: ernstjan.speel@mumc.nl

*(R G Riedl is now at Department of Pathology, Zuyderland Hospital, Sittard-Geleen, The Netherlands)

\begin{abstract}
Clinical and molecular studies have implicated epidermal growth factor receptor (EGFR), insulin-like growth factor (IGF) and target of rapamycin (mTOR) signaling pathways in the regulation of pancreatic neuroendocrine tumor (PanNET) growth. Interpretation and comparison of these studies is complex due to clinical and molecular tumor heterogeneity. We therefore focused in this study on insulinomas, which we examined for mRNA and protein expression of EGFR, IGF and mTOR signaling pathway components by quantitative real-time PCR $(n=48)$ and immunohistochemistry $(n=86)$. Findings were compared with normal pancreatic islets and correlated with histopathological data and clinical outcome. Insulinomas showed low EGFR and high IGF2 expression. IGFBP2, IGFBP3 and IGFBP6 mRNA levels were 2- to 4-folds higher than those in islets. High protein expression of IGF2, IGF1R and INSR (in 51-92\% of the tumors) and low-to-moderate expression of mTORC1 pathway proteins $\mathrm{p}-\mathrm{S} 6 \mathrm{k}$ and $\mathrm{p}-4 \mathrm{EBP} 1$ (7-28\% of the tumors) were observed. Correlations were found between (1) ERK1 mRNA expression and that of numerous IGF pathway genes, (2) p-ERK and IGF1R protein expression and (3) decrease of IGF pathway components and both metastatic disease and shorter 10-year disease-free survival. In conclusion, our observations suggest that high expression of IGF signaling pathway components is a hallmark of insulinomas, but does not necessarily lead to increased mTOR signaling. Reduced expression of IGF pathway components may be an adverse prognostic factor in insulinomas.
\end{abstract}

Endocrine-Related Cancer (2018) 25, 1005-1018

\section{Introduction}

Over the past years, advances have been made in understanding the biology and clinical behavior of gastroenteropancreatic neuroendocrine tumors (GEP-NETs), a heterogeneous group of tumors arising

from the diffuse neuroendocrine system (Oberg 2012, Muniraj et al. 2013). The estimated annual incidence of NETs in the USA increased 6.4-fold between 1973 and 2012, with an incidence rate of 3.56/100,000 in 
gastroenteropancreatic sites (Dasari et al. 2017). GEP-NETs can be divided, based on clinical manifestations, into functioning (syndrome-related) and non-functioning tumors. Today, PanNETs are treated by surgery, biotherapy, chemotherapy and/or molecular targeted therapy using multidisciplinary therapeutic management. Since 2011, the FDA approved the mammalian target of rapamycin (mTOR) inhibitor everolimus for the treatment of progressive PanNETs and well-differentiated, nonfunctional GEP-NETs and lung-NETs (RADIANT-3 and -4 studies) (Yao et al. 2011, 2016). mTOR regulates cell survival, proliferation and motility and also senses cell energy status (Gentzler et al. 2012).

Because of the heterogeneity of PanNETs, analysis of the underlying molecular biology is essential for successful targeted treatment. The basis of positive treatment results for everolimus is derived from a number of studies implicating mTOR pathway alterations in the proliferation of PanNETs. (Jiao et al. 2011) found mutations in the mTOR pathway genes PTEN and TSC2 in 14\% of (nonfunctioning) PanNETs. Moreover, (Missiaglia et al. 2010) reported downregulation of PTEN and TSC2, inhibitors of the mTOR pathway, in up to $70 \%$ of non-functioning and functioning PanNETs, including insulinomas. Wholegenome sequencing of insulinomas revealed mutations in the gene $Y Y 1$, a target of mTOR, in 30\% of the tumors (Cao et al. 2013). Finally, several immunohistochemical studies showed positivity for mTOR pathway proteins p-mTOR (range 60-70\%), p-S6K (40-80\%) and p-4EBP1 (30-90\%) in GEP-NETs (Kasajima et al. 2011, Zhan et al. 2012, Qian et al. 2013). However, interpretation and comparison of these studies is complex due to the fact that GEP-NETS/PanNETs comprise heterogeneous tumor subtypes with different clinical and molecular characteristics, and studies have used different diagnostic tools and evaluation criteria to detect alterations in the mTOR pathway.

The mTOR pathway can be activated by various upstream stimuli, including epidermal growth factor receptor (EGFR) and the insulin-like growth factor (IGF) signaling system, which play a pivotal role in cancer development and progression. EGFR activation promotes cell proliferation via MAPK and PI3K signaling routes, and indications for a role of EGFR signaling in PanNETs have been reported. Immunohistochemical analysis of EGFR expression showed positivity in 30-65\% of mixed populations of PanNETs (Srivastava et al. 2001, Papouchado et al. 2005, Bergmann et al. 2009). The IGF signaling system includes the ligands IGF1 and IGF2, the receptors IGF1R, IGF2R and insulin receptor (INSR) and 6 IGF-binding proteins (IGFBP1-6) (Lodhia et al. 2015). Deregulation of the IGF signaling system, for example by upregulation of IGF1R, IGF2 and IGFBP2, has been reported in several malignancies, including GEP-NETs/PanNETs and insulinomas (Wulbrand et al. 2000, Dejeux et al. 2009, Ludovini et al. 2009, Livingstone 2013).

In this study, we evaluated mRNA and protein expression patterns of EGFR and IGF signaling pathway components that may regulate the mTOR pathway, as well as the mTORC1 pathway downstream effectors p70S6 Kinase (S6K) and 4E-BP1 (4EBP1) in a large series of insulinomas. Quantitative real-time PCR (qRT-PCR) and immunohistochemistry (IHC) data were correlated with each other, with histopathology and with clinical patient and follow-up data.

\section{Materials and methods}

A detailed description of materials and methods can be found in Supplementary materials and methods (see section on supplementary data given at the end of this article).

\section{Patient samples}

Detailed data on insulinoma patient's age, sex, disease stage and tumor grade and size are provided as Supplementary Table 1 (Jonkers et al. 2007, Marinoni et al. 2014). All insulinoma patients had hyperinsulinism followed by a hypoglycemia syndrome. The initial treatment consisted of surgical removal of the primary tumor, and if present liver and/or lymph node metastases. Follow-up treatment for patients with metastatic disease included surgery, transarterial embolization or transarterial chemoembolization. The tumors were all sporadic, not associated with MEN1 syndrome and classified according to the World Health Organization 2010 staging and grading system.

From 48 insulinoma patients, snap-frozen tumor tissue was available for RNA analysis, and from 26 patients also formalin-fixed, paraffin-embedded material.

Two paraffin-embedded tissue microarrays (TMAs) were available for immunohistochemical analysis, containing 49 insulinomas (TMA1) and a second TMA with 11 additional insulinomas (TMA2). TMA1 furthermore contained 92 additional PanNETs (12 gastrinomas, 11 glucagonomas, 10 vipomas and 59 non-functioning PanNETs), of which data can be found in Supplementary Table 6. Patient material was used according to the 
Code for Proper Secondary Use of Human Tissue in The Netherlands (https://www.federa.org/, update 2011) and according to the cantonal ethics committee of Bern (KEK-BE 105-2015).

\section{RNA isolation}

Total RNA was isolated from snap frozen insulinomas using the Qiagen RNeasy Mini Kit and had a RIN value $\geq 6.5$.

Control MPV Total RNA from normal human pancreas, liver, lung and adrenal gland (Stratagene) and total RNA from normal, single donor human pancreatic islets (a gift of Dr E de Koning, Leiden University Medical Center, The Netherlands) were included as controls.

\section{Quantitative real-time PCR}

Total RNA was converted to cDNA using the iScript cDNA Synthesis Kit (Bio-Rad Laboratories). qRT-PCR reactions were performed using two commercially available SYBR green mixes, iQ SYBR Green Supermix (Bio-Rad) and SensiMix SYBR and Fluorescein Kit (BioLine). All primers (Supplementary Table 2) were purchased from Biolegio.

\section{Immunohistochemistry}

Immunohistochemical staining on freshly cut $4 \mu \mathrm{m}$-thick formalin-fixed, paraffin-embedded tissue sections was performed using primary antibodies against EGFR, IGF2, IGF1R, INSR, p-AKT, p-ERK, p-S6K and p-4EBP1. Detailed information on antibodies and staining conditions can be found in Supplementary Table 3.

Immunohistochemical staining was scored as: 0 , absent; 1 , weakly positive in $\geq 10 \%$ of cells; 2 , moderately positive in $\geq 10 \%$ of cells; 3 , strongly positive in $\geq 10 \%$ of cells.

\section{Statistical analysis}

Statistical analysis was performed using SPSS version 20 (IBM). Mean relative gene expression levels between groups were compared with the $F$-test and Student $t$-test. Associations between relative gene expression levels and immunostaining levels were determined using Pearson's correlation. All $P$ values were considered statistically significant if $\leq 0.05$ in two-sided tests.

Survival curves were created using the Kaplan-Meier method, the log-rank test was used to test for differences between subgroups. Details on assessment of disease-free or overall survival rates can be found in the Supplementary materials and methods. Cox-regression was used for multivariate analysis.

\section{Results}

mRNA expression in insulinomas

\section{Neuroendocrine markers}

From 48 insulinomas, mRNA was analyzed. To check for the endocrine nature of the tumors the relative mRNA expression levels of insulin (INS), chromogranin (CGA) and synaptophysin (SYP) were analyzed by quantitative RT-PCR (qRT-PCR). In addition, mRNA from normal human tissues (whole pancreas, pancreatic islets, liver, lung and adrenal gland) was analyzed as controls. Expression levels were normalized to glucuronidase beta (GUSB), which exhibited the most stable expression level in all samples after comparing the expression levels of four housekeeping genes.

Table 1 shows high mean and median expression levels of INS, CGA and SYP mRNA (8351, 89 and 2.3 normalized to GUSB, respectively), consistent with the neuroendocrine character of insulinomas. In normal pancreatic islets, the mRNA expression levels of INS, CGA and SYP were respectively 4151, 15 and 0.5. In normal pancreatic tissue, the mRNA levels for these genes were significantly lower. Normal adrenal mRNA showed a high expression level of CGA (57) and SYP (1.3), but very low INS expression (0.2). In normal liver and lung tissue very low mRNA expression levels of CGA, SYP and INS were found (data not shown; analyses of normal controls were performed three times in duplicate). When compared to normal pancreatic islets the mean expression levels of INS, CGA and SYP mRNA in insulinomas showed a 2.0, 6.0 and 4.8 fold increase, respectively (Table 1 ).

\section{EGFR, ERK and $A K T$}

Since EGFR signaling via MAPK and AKT pathways has been reported to be active in PanNETs, we examined the mRNA expression levels of EGFR, ERK1, ERK2 and AKT in the 48 insulinomas. EGFR mRNA expression was low $(0.10)$, with a relative expression of 0.15 as compared to normal pancreatic islets (Table 1). ERK1, ERK2 and $A K T$ mRNA expression levels were 1.1, 1.6 and 2.6, respectively. ERK1 expression was at the same level as in normal pancreatic islets, while the relative expression levels of ERK2 and AKT showed a 0.3- and 0.2-fold decrease. 
Table 1 Mean mRNA expression levels of neuroendocrine related genes and genes in the MAPK/AKT and IGF pathway in 48 insulinomas.

\begin{tabular}{|c|c|c|c|c|}
\hline & \multicolumn{2}{|c|}{ Normalized to GUSB } & \multicolumn{2}{|c|}{ Relative to pancreatic islets } \\
\hline & Mean (s.D.) & Median & Mean (S.D.) & Median \\
\hline$\overline{C G A}$ & $88.91 \pm 95.94$ & 59.94 & $6.04 \pm 6.61$ & 3.92 \\
\hline SYNAPT & $2.28 \pm 1.92$ & 1.83 & $4.83 \pm 4.31$ & 3.61 \\
\hline INS & $8351.20 \pm 8507.11$ & 6269.65 & $2.01 \pm 2.03$ & 1.48 \\
\hline$E G F R$ & $0.10 \pm 0.10$ & 0.07 & $0.15 \pm 0.17$ & 0.11 \\
\hline$A K T$ & $2.58 \pm 1.45$ & 2.28 & $0.75 \pm 0.45$ & 0.63 \\
\hline$E R K 1$ & $1.10 \pm 0.73$ & 0.93 & $1.03 \pm 0.64$ & 0.95 \\
\hline ERK2 & $1.56 \pm 0.89$ & 1.45 & $0.68 \pm 0.49$ & 0.55 \\
\hline IGF1 & $0.04 \pm 0.13$ & 0.01 & NA & \\
\hline IGF1R & $0.11 \pm 0.12$ & 0.06 & $0.82 \pm 0.92$ & 0.49 \\
\hline IGF2 & $1.46 \pm 3.12$ & 0.43 & $12.44 \pm 22.64$ & 3.54 \\
\hline$I G F 2 R$ & $0.13 \pm 0.09$ & 0.11 & $0.67 \pm 0.42$ & 0.58 \\
\hline IGFBP1 & $0.03 \pm 0.07$ & 0.00 & $1.63 \pm 4.13$ & 0.16 \\
\hline IGFBP2 & $4.81 \pm 5.69$ & 3.44 & $4.04 \pm 4.41$ & 3.18 \\
\hline IGFBP3 & $0.21 \pm 0.32$ & 0.09 & $2.86 \pm 4.74$ & 1.24 \\
\hline IGFBP6 & $0.23 \pm 0.32$ & 0.12 & $2.03 \pm 1.99$ & 1.37 \\
\hline INSR-A & $0.22 \pm 0.20$ & 0.19 & $1.30 \pm 0.70$ & 1.27 \\
\hline INSR-B & $0.10 \pm 0.09$ & 0.08 & $0.75 \pm 0.54$ & 0.70 \\
\hline MTOR & $0.01 \pm 0.01$ & 0.01 & $0.35 \pm 0.44$ & 0.22 \\
\hline RPS6KB1 & $0.02 \pm 0.02$ & 0.01 & $0.58 \pm 0.61$ & 0.39 \\
\hline EIF4EBP1 & $0.84 \pm 0.87$ & 0.58 & $0.45 \pm 0.46$ & 0.30 \\
\hline
\end{tabular}

IGF1 relative to pancreatic islets cannot be calculated since IGF1 was not detectable in normal pancreatic islets.

\section{IGF pathway}

Table 1 shows the mRNA expression levels of IGF pathway-related genes in insulinomas. In contrast to very low IGF1 levels, the mean mRNA expression level of IGF2 is 1.5 , which is a 12.4 -fold increase compared to normal pancreatic islets (median: 3.5 fold increase). IGFBP2 has an expression level of 4.8 , which is 4.0 -fold higher than that in normal pancreatic islets. Despite the fact that IGFBP3 and IGFBP6 showed expression levels of 0.21 and 0.23 (normalized to GUSB), their relative expression was 2-3 folds higher than that in normal pancreatic islets. The other IGF pathway genes showed low expression levels $(0.01-0.2)$.

\section{mTOR pathway}

The mean mRNA expression levels of MTOR and RPS6KB1 (coding for S6K protein) were low (0.01-0.02) in insulinomas, whereas EIF4EBP1 (coding for 4EBP1 protein) is expressed at the level of GUSB (Table 1). In normal pancreatic islets, all three genes showed a 0.4-0.6 fold decreased mRNA expression level.

In conclusion, insulinomas show low expression levels of EGFR mRNA, high expression of $I G F 2$, a 2-4 fold increased expression of IGFBP2, IGFBP3 and IGFBP6, and a twofold reduced expression of MTOR, RPS6KB1 and EIF4EBP1, as compared to pancreatic islets.

\section{Correlations between mRNA expression patterns}

Pearson correlation analysis between mRNA expression levels of different signaling pathway genes is shown in Supplementary Table 4. Correlations between substantially expressed genes include those (1) between ERK1, ERK2 and $A K T$ and (2) between ERK1 and IGF pathway genes IGFBP2 (inverse correlation), IGFBP6, and all receptors (detailed information in Supplementary Table 4). IGF2, IGFBP3 (except for SYP) and EIF4EBP1 expression levels did not correlate with the other analyzed genes.

\section{Protein expression in insulinomas}

\section{EGFR, ERK and AKT}

Immunostaining was performed on 86 insulinomas, including 26 that were also analyzed for mRNA expression levels (see above), and 60 cases present as single or duplicate cores on the TMAs. All tumors were negative for EGFR, which is in agreement with the low assessed EGFR mRNA expression levels. As a positive control a human premalignant laryngeal lesion was used, showing strongly positive membranous staining. In normal human pancreas a low number of acinar cells showed a weakly positive membranous staining, whereas the islet cells were negative for EGFR (Table 2 and Fig. 1A, $\mathrm{B}$ and $\mathrm{C})$. 
Table 2 Immunohistochemical expression of proteins in the EGFR/MAPK/AKT/IGF/mTOR pathways in insulinomas, presented as percentage of the samples with a specified staining intensity.

\begin{tabular}{|c|c|c|c|}
\hline Insulinomas & Negative & Weakly positive & Positive \\
\hline EGFR & 100 & 0 & 0 \\
\hline $\mathrm{p}-\mathrm{AKT}$ nuclear & 60 & 18 & 22 \\
\hline p-AKT cytoplasmic & 51 & 41 & 8 \\
\hline p-ERK nuclear & 30 & 38 & 32 \\
\hline p-ERK cytoplasmic & 38 & 38 & 24 \\
\hline IGF2 & 1 & 7 & 92 \\
\hline IGF1R cytoplasmic & 4 & 18 & 78 \\
\hline IGF1R membranous & 38 & 11 & 51 \\
\hline INSR cytoplasmic & 4 & 13 & 83 \\
\hline $\mathrm{p}-\mathrm{S} 6 \mathrm{~K}$ nuclear & 72 & 9 & 19 \\
\hline p-S6K cytoplasmic & 72 & 16 & 12 \\
\hline $\mathrm{p}-4 \mathrm{EBP} 1$ nuclear & 93 & 3 & 4 \\
\hline p-4EBP1 cytoplasmic & 78 & 13 & 9 \\
\hline
\end{tabular}

Staining intensity was defined as negative, weakly positive in $\geq 10 \%$ of cells and moderately or strongly positive in $\geq 10 \%$ of cells. p, phosphorylated.

Table 2 shows the IHC data for p-AKT and p-ERK. A lung carcinoma harboring a K-ras exon 2 mutation served as positive control (Supplementary Fig. 1A and $\mathrm{B}$ respectively). A moderate-to-strong nuclear p-AKT expression was seen in normal pancreatic islet cells, whereas the acinar cells were negative. In normal pancreas no p-ERK could be detected. Moderately to strongly positive nuclear p-AKT staining was observed in $22 \%$ and nuclear p-ERK in 32\% of insulinomas (Fig. 1D, $\mathrm{E}$ and F). Twenty-four percent of the insulinomas showed neither nuclear nor cytoplasmic p-ERK staining; 36\% were negative for p-AKT. Moderate-to-strong simultaneous expression of nuclear p-AKT and p-ERK was found in 10\% of the tumors, while in $22 \%$, no coexpression of nuclear p-AKT and p-ERK could be detected (double-negative).

\section{IGF pathway proteins}

IHC results for IGF pathway proteins IGF2 and receptors IGF1R and INSR are shown in Table 2 and Fig. 1G, H, I, J, K, L, M, N and O. In 92\% of the insulinomas, a strong cytoplasmic, diffusely granular pattern of IGF2 was observed. A similar pattern of lower intensity was seen in normal pancreatic islet cells, whereas acinar cells showed a strong, aggregated extracellular IGF2 localization, which could be a sign of internalization of IGF1R and/or INSR after ligand binding (Rajapaksha \& Forbes 2015).

Tumors indeed exhibited high, diffuse cytoplasmic expression levels of IGF1R and INSR (78\% and 83\%, respectively), while in $51 \%$ of the cases also a membranous
IGF1R staining and in 38\% a perinuclear localization of INSR was observed.

These patterns could also be recognized in the normal pancreas, i.e. the islet cells showed a granular cytoplasmic IGF1R and INSR expression pattern, whereas the acinar compartment showed a membranous IGF1R localization, and a cytoplasmic INSR expression with perinuclear localization.

These data indicate that the IGF pathway is active in insulinomas.

\section{mTORC1 pathway proteins $\mathrm{p}-\mathrm{S} 6 \mathrm{~K}$ and $\mathrm{p}-4 \mathrm{EBP} 1$}

Figure 2 (A, B, C, D, E and F) and Table 2 show the IHC results for $\mathrm{p}-\mathrm{S} 6 \mathrm{~K}$ and $\mathrm{p}-4 \mathrm{EBP} 1$. Normal human colon tissue served as positive control (Supplementary Fig. 1C and D).

In $28 \%$ of insulinomas, a weakly to moderately positive cytoplasmic p-S6K staining pattern was seen. Also $28 \%$ of tumors showed nuclear staining. Normal pancreatic islets showed the same staining pattern but with lower intensity. In contrast, in approximately $75 \%$ of normal pancreatic acinar cells, a moderately to strongly positive perinuclear and/or diffuse nuclear p-S6K staining was detected. Interestingly, in tumor adjacent pancreatic tissue, we observed a stronger p-S6K staining in acinar and islet cells than in normal control pancreatic tissue (data not shown).

Only $37 \%$ of insulinomas exhibited a weakly to moderately positive nuclear p-4EBP1 staining, and in $22 \%$ also cytoplasmic staining was detected (Table 2). Normal pancreatic islets did not show p-4EBP1 expression, and areas, predominantly at the periphery of lobules, showed a moderately to strongly positive diffuse cytoplasmic, and in 90\% also strong nuclear, immunostaining in acinar cells (Fig. 2D and E). Strikingly, exocrine pancreatic tissue adjacent to the tumor often displayed a stronger nuclear and cytoplasmic immunostaining.

In conclusion, insulinomas show high expression levels of IGF2, IGF1R and INSR, no EGFR expression and low levels of phosphorylated mTORC1 pathway proteins.

\section{Positive correlations between protein expression patterns}

Pearson correlation analysis of protein expression levels shows a correlation of IGF2 with cytoplasmic IGF1R $(P=0.019)$. The latter also correlates with nuclear $\mathrm{p}$-ERK $(P=0.003)$, which in turn correlates with nuclear $\mathrm{p}$-AKT $(P=0.011)$ and nuclear p-S6K $(P=0.002)$. In addition, cytoplasmic INSR correlates with nuclear p-S6K $(P=0.024)$ (Supplementary Table 5). 

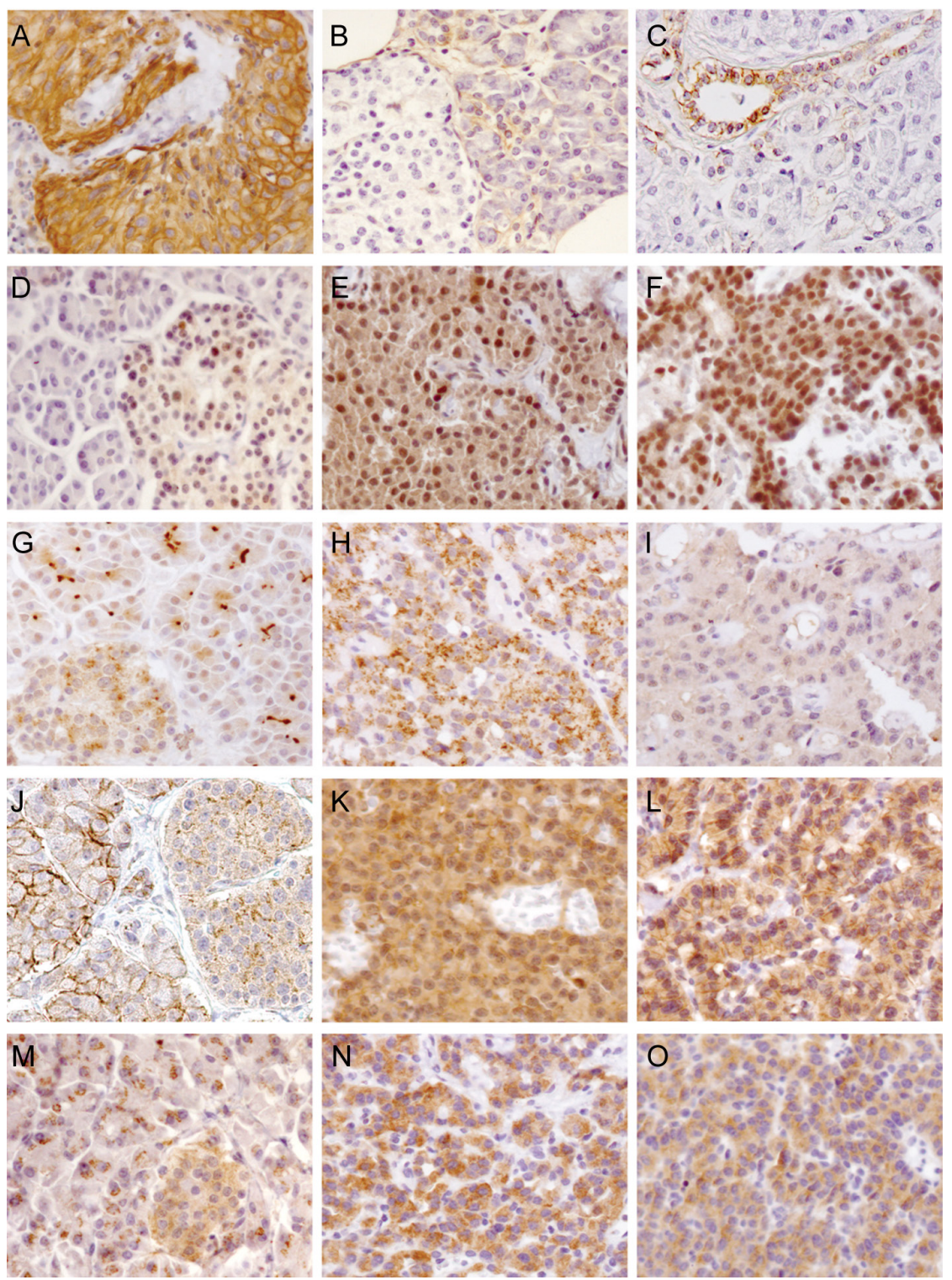

\section{Figure 1}

Representative examples of immunohistochemical EGFR, p-AKT, p-ERK, IGF2, IGF1R and INSR protein expression in human tissue: normal pancreas ( $B, D, G, J$ and $M)$, a premalignant laryngeal lesion (A) and insulinomas (C, E, F, H, I, K, L, N and O). Strong membranous EGFR expression in a premalignant laryngeal lesion (A), weakly positive expression in normal acinar cells, and no detectable expression in the islets (B) and in insulinomas (C). Moderate-to-strong nuclear p-AKT expression in normal pancreatic islets (D) and moderate-to-strong nuclear and moderate cytoplasmic expression in an insulinoma (E). Strong nuclear $p$-ERK immunostaining in an insulinoma (F). Strong aggregate like, extracellular IGF2 localization in normal acinar cells, and a moderate, diffuse granular cytoplasmic staining pattern in pancreatic islets (G). Strong, granular cytoplasmic IGF2 expression in a non-metastatic insulinoma and weakly positive, diffuse cytoplasmic expression in a metastatic insulinoma ( $\mathrm{H}$ and I respectively). Strongly positive, membranous IGF1R expression in normal acinar cells and moderately positive, granular cytoplasmic expression pattern in islet cells (J). In insulinomas a strong, cytoplasmic expression (K) or combined cytoplasmic and membranous IGF1R expression pattern (L) is seen. Moderate-to-strong cytoplasmic, perinuclear INSR expression in normal acinar cells with a granular, cytoplasmic pattern in islet cells (M). Moderate, diffuse granular and strong perinuclear INSR expression (N) or weak to moderate, diffuse expression $(\mathrm{O})$ in insulinomas. Original magnifications $200 x$.

\section{Correlation of mRNA and protein expression with clinicopathologic parameters in insulinomas}

Mean relative gene expression levels of insulinoma subgroups were compared using Student's $t$-test (Table 3). Of the 20 genes analyzed, only the relative expression level of $I G F 2 R$ compared to normal pancreatic islets was significantly lower in grade $2 / 3$ than in grade 1 insulinomas $(P=0.039)$. A decrease in expression in grade $2 / 3$ tumors was also seen for IGF1R, INS and IGF2, although not statistically significant. At the protein level (Table 4), a significantly lower membranous INSR and cytoplasmic p-4EBP1 staining intensity was found in grade $2 / 3$ as compared to grade 1 insulinomas ( $P=0.004$ and $P=0.001$, respectively).
The mean mRNA expression level of INS relative to normal pancreatic islets was significantly lower in metastatic insulinomas than in non-metastatic $(P<0.0001)$. In contrast, the relative expression of IGFBP3 was higher in metastatic tumors, although the difference was not statistically significant. The protein expression levels of IGF2, cytoplasmic IGF1R and INSR, membranous INSR and cytoplasmic p-S6K were significantly lower in metastatic tumors than in non-metastatic tumors $(P=0.001, P=0.026, P=0.035, P=0.004$ and $P=0.030$, respectively).

Comparison of the mean mRNA expression levels between tumors $<$ and $\geq 2 \mathrm{~cm}$ revealed INS and EIF4EBP1 mRNA levels to be significantly lower in tumors $\geq 2 \mathrm{~cm}$ http://erc.endocrinology-journals.org https://doi.org/10.1530/ERC-18-0222
(C) 2018 Society for Endocrinology Published by Bioscientifica Ltd. Printed in Great Britain 

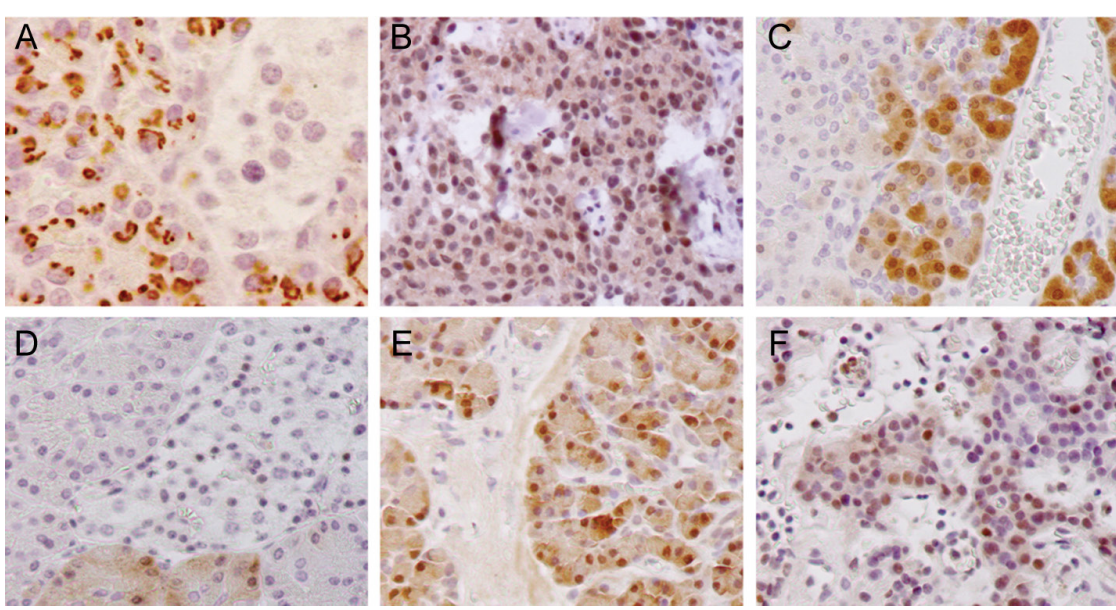

Figure 2

Representative examples of immunohistochemical $\mathrm{p}$-S6K and p-4EBP1 protein expression in normal human pancreatic tissue and insulinomas. Strong, perinuclear expression pattern of $\mathrm{p}-\mathrm{S6K}$ in normal acinar cells, while the islets cells show a very weak, diffuse cytoplasmic expression (A). Weak cytoplasmic and moderate to strong nuclear expression of p-S6K in insulinoma (B). Moderately to strongly positive diffuse cytoplasmic and nuclear p-4EBP1 immunostaining in normal exocrine pancreas cells at the periphery of a lobule (C). No detectable p-4EBP1 expression in normal pancreatic islet (D). Strong nuclear and weak-to-moderate cytoplasmic p-4EBP1 expression in tumor adjacent exocrine tissue $(\mathrm{E})$. Moderate-to-strong nuclear and weak cytoplasmic p-4EBP1 expression in insulinoma (F).
( $P=0.009$ and $P=0.003$, respectively). This was also observed for IGF2 protein expression $(P=0.001)$.

A higher disease stage (stage IV vs stage I+II) correlated with a lower expression of INS, IGF2 and IGF1R $m R N A$, as well as IGF2, p-ERK (nuclear and cytoplasmic), cytoplasmic IGF1R and membranous INSR protein.

In conclusion, insulinomas appear to reduce IGF pathway gene expression both at the mRNA and protein level in relation to tumor grade, metastatic potential, size and disease stage.

\section{Correlation of mRNA and protein expression and clinicopathologic parameters with survival in insulinomas}

Lower mRNA expression levels of INS, IGF1R and INSR- $A \quad(P \leq 0.019$ for disease-free and $P \leq 0.032$ for overall survival) and higher levels of IGFBP3 $(P<0.0001$ for disease-free and $P=0.001$ for overall survival) correlated with shorter 10-year survival (Fig. 3 and Supplementary Fig. 2).

Lower protein levels of cytoplasmic IGF2, IGF1R and INSR ( $P \leq 0.035$ for disease-free survival; $P \leq 0.033$ for overall survival) correlated with shorter 10-year survival rates (Fig. 4 and Supplementary Fig. 3).

Univariate analysis of clinicopathological parameters of tumors showed very strong associations of grade, metastatic disease, tumor size and disease stage with both 10-year disease-free and overall survival $(P<0.0001)$ (Fig. 3 and Supplementary Fig. 2E, F, G and H, and Fig. 4 and Supplementary Fig. 3D, E, F and G).

In Table 5 a summary of parameters that correlate with disease outcome in univariate analysis results is shown.

When comparing high vs low gene expression of either INS, IGF1R, INSR-A or IGFBP3 with grade, metastatic disease and tumor size in multivariate analysis, no significant associations were found. In multivariate analysis of moderate vs high IGF2 protein expression, grade and tumor size, grade $(P=0.024, H R$ 6.81) and tumor size $(P=0.022$, HR 17.77$)$ were significantly correlated with 10-year survival. When comparing IGF1R (high vs low expression) with grade and tumor size in multivariate analysis only tumor size $(P=0.032$, HR 7.03$)$ correlated with 10-year survival. This was also found when comparing INSR (high vs low expression) in multivariate analysis with grade and tumor size (tumor size: $P=0.007$, HR 9.31).

Table 3 Correlation of mRNA expression levels in insulinomas, relative to normal single donor pancreatic islet mRNA, with grade, tumor size, metastatic disease and disease stage.

\begin{tabular}{|c|c|c|c|c|}
\hline \multirow[b]{2}{*}{ mRNA } & \multicolumn{4}{|c|}{$P$-Value } \\
\hline & $\begin{array}{c}\text { Grade } 1 \\
\text { vs Grade } \\
2+3 \\
\end{array}$ & $\begin{array}{c}\text { Non-metastatic } \\
\text { vs metastatic }\end{array}$ & $\begin{array}{c}\text { Tumor size } \\
<2 \mathrm{~cm} \text { vs } \geq 2 \mathrm{~cm}\end{array}$ & $\begin{array}{c}\text { Disease stage } \\
\text { I+ II vs IV }\end{array}$ \\
\hline INS & NS & $<0.0001$ & 0.009 & $<0.0001$ \\
\hline$A K T$ & NS & NS & NS & NS \\
\hline$E R K 1$ & NS & NS & NS & NS \\
\hline$E R K 2$ & NS & NS & NS & NS \\
\hline$I G F 2$ & NS & NS & NS & 0.004 \\
\hline IGF1R & NS & NS & NS & 0.024 \\
\hline$I G F 2 R$ & 0.039 & NS & NS & NS \\
\hline$I G F B P 2$ & NS & NS & NS & NS \\
\hline IGFBP3 & NS & NS & NS & NS \\
\hline IGFBP6 & NS & NS & NS & NS \\
\hline INSR-A & NS & NS & NS & NS \\
\hline INSR-B & NS & NS & NS & NS \\
\hline EIF4EBP1 & NS & NS & 0.003 & NS \\
\hline RPS6KB1 & NS & NS & NS & NS \\
\hline
\end{tabular}

$P$-Values $\leq 0.05$ correspond to lower specific gene expression in tumors with higher grade, metastatic progression, larger size and more advanced disease stage.

NS, not significant.
2018 Society for Endocrinology Published by Bioscientifica Ltd. Printed in Great Britain 
Table 4 Correlation of protein expression levels with grade, tumor size, metastatic disease and disease stage.

\begin{tabular}{|c|c|c|c|c|}
\hline \multirow[b]{2}{*}{ Protein } & \multicolumn{4}{|c|}{ P-Value } \\
\hline & Grade 1 vs Grade $2+3$ & Non-metastatic vs metastatic & Tumor size $<2 \mathrm{~cm}$ vs $\geq 2 \mathrm{~cm}$ & Disease stage I+ II vs IV \\
\hline IGF2 & NS & 0.001 & 0.001 & 0.009 \\
\hline p-AKT nuclear & NS & NS & NS & NS \\
\hline p-AKT cytoplasmic & NS & NS & NS & NS \\
\hline p-ERK nuclear & NS & NS & NS & 0.004 \\
\hline p-ERK cytoplasmic & NS & NS & NS & 0.006 \\
\hline IGF1R cytoplasmic & NS & 0.026 & NS & 0.021 \\
\hline IGF1R membranous & NS & NS & NS & NS \\
\hline INSR cytoplasmic & NS & 0.035 & NS & NS \\
\hline INSR membranous & 0.004 & 0.004 & NS & 0.004 \\
\hline p-4EBP1 nuclear & NS & NS & NS & NS \\
\hline p-4EBP1 cytoplasmic & 0.001 & NS & NS & NS \\
\hline p-PS6K cytoplasmic & NS & 0.030 & NS & NS \\
\hline
\end{tabular}

$P$-Values $\leq 0.05$ correspond to lower specific protein expression in tumors with higher grade, metastatic progression, larger size and more advanced disease stage.

NS, not significant; $p$, phosphorylated.

\section{Protein expression analysis in PanNETs other than insulinomas}

We also analyzed protein expression in 92 PanNETs other than insulinomas, which were available on the TMA1. Data evaluation and analysis are available as Supplementary data (Supplementary Results and Supplementary Tables 6, 7 and 8).

\section{Discussion}

Since PanNETs are a heterogeneous group of neoplasms, understanding the underlying molecular biology of the different subgroups is essential to offer adequate treatment (Cives et al. 2016). Our study focused on mRNA and protein expression of EGFR, IGF and mTOR signaling pathway components in insulinomas. We found that, compared to pancreatic islets, insulinomas show low expression levels of EGFR mRNA, high expression of IGF2, a 2-4 fold increased expression of IGFBP2, IGFBP3 and IGFBP6, and a twofold reduced expression of $M T O R, R P S 6 K B 1$ and EIF4EBP1. At the protein level, high expression levels of IGF2, IGF1R and INSR were detected, whereas no EGFR and relatively low levels of mTOR pathway proteins were observed. Correlation of expression data with clinicopathological data revealed a decrease of several IGF pathway components in relation to tumor grade, metastatic disease, tumor size and disease stage. Low mRNA expression levels of IGF2, $I G F 1 R$ and INSR-A, but high levels of IGFBP3 correlated with shorter 10-year overall and disease-free survival. Decreased protein expression of IGF2, cytoplasmic IGF1R and INSR also correlated with shorter survival rates.
Activated EGFR enhances tumor growth, invasion and metastatic spread and promotes cell survival. Abnormal expression of (mutated) EGFR is often found in neoplasms, particularly in breast, non-small-cell lung, head and neck and colorectal cancer, which is utilized in targeted therapy with TKIs or antibodies directed against EGFR (Ciardiello \& Tortora 2008, Garraway \& Janne 2012). An initial phase II trial using gefitinib treatment of PanNETs, however, did not show much efficacy, i.e. no objective responses and a 6-month progression-free survival of $10 \%$ for islet cell carcinomas (Hobday et al. 2006). In our study, we found low levels of EGFR mRNA and neither detectable protein expression in insulinomas and normal pancreatic islets. These data thus may explain the low efficacy of EGFR inhibitors in the treatment of PanNETs. Nevertheless, other studies have reported detectable expression of EGFR in 18-66\% of the tumors (Wulbrand et al. 1998, Srivastava et al. 2001, Fjallskog et al. 2003, Papouchado et al. 2005, Gilbert et al. 2013), with low expression in benign PanNETs and high expression rates in both well-differentiated PanNETs and poorly differentiated pancreatic neuroendocrine carcinomas (Bergmann et al. 2009). In these studies, however, mixed groups of PanNETs were subjected to immunohistochemical staining protocols differing in, among others pretreatment steps, primary antibodies and evaluation criteria. We have utilized a commonly used EGFR immunostaining protocol and a primary EGFR-specific antibody, resulting in intense EGFR membrane staining in head and neck premalignancy control specimens as well as in pancreatic ducts adjacent to negative insulinomas. Based on our results, we can 
A

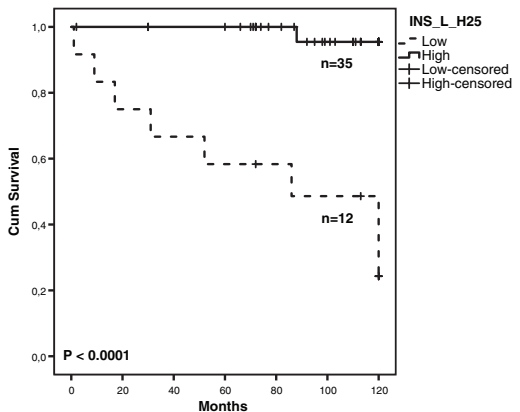

C

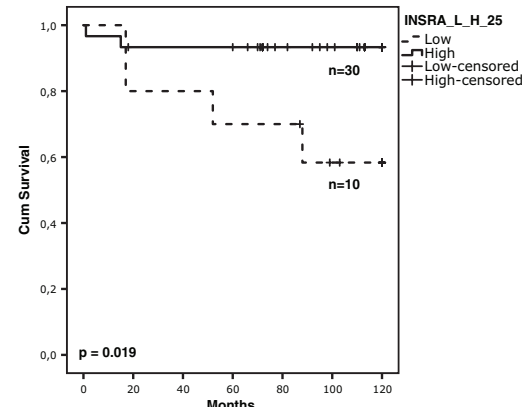

E

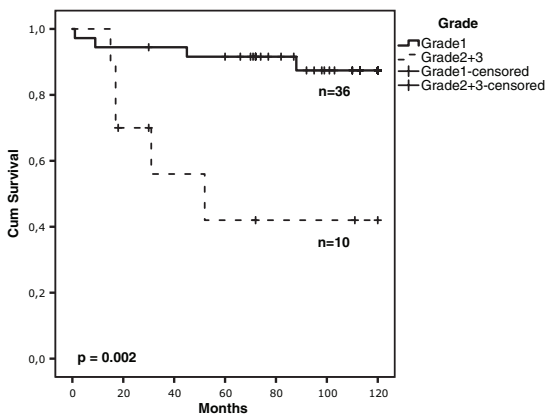

G

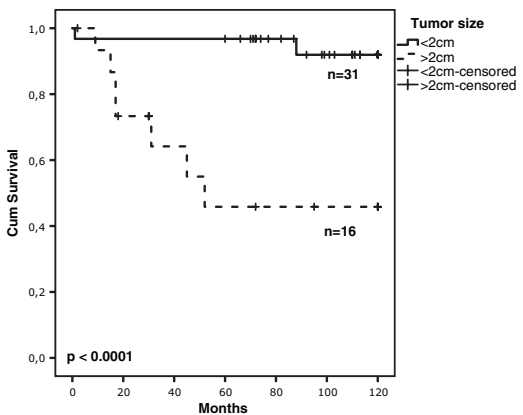

B

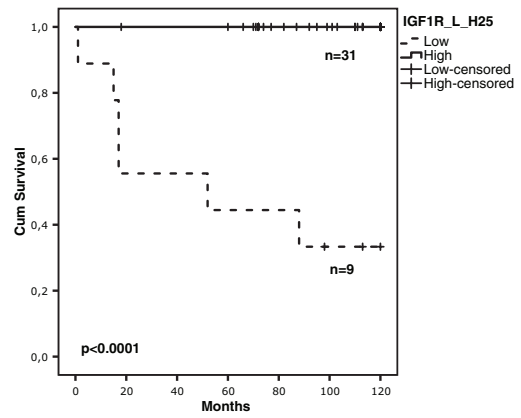

D

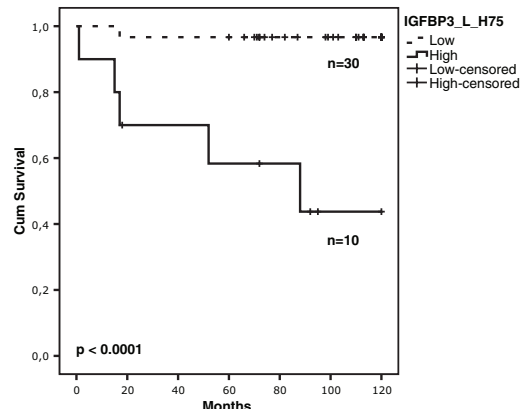

$\mathrm{F}$

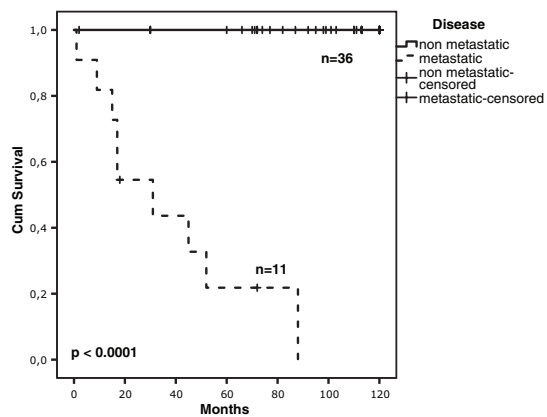

$\mathrm{H}$

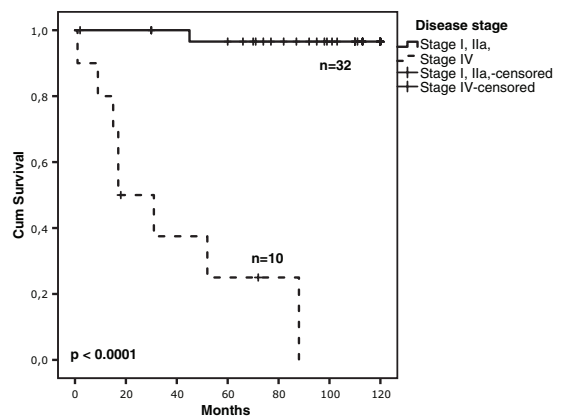

Figure 3

Kaplan-Meier analysis showing 10-year disease-free survival rates of insulinoma patients with regard to mRNA expression (A, B, C and D) and clinicopathological parameters $(E, F, G$ and $H)$. Correlation between survival and mRNA expression, (A) INS (cut-off 25th percentile), (B) IGF1R (cut-off 25th percentile), (C) INSR-A (cut-off 25th percentile), (D) IGFBP3 (cut-off 25th percentile), (E) Grade (Grade1 vs Grade 2+3), (F) Disease (non-metastatic vs metastatic), (G) Tumor size $(<2 \mathrm{~cm}$ vs $\geq 2 \mathrm{~cm}$ ) and (H) Disease stage (Stage I+ lla vs IV). Dotted lines in plot (A, B, C and D) refer to low expression. conclude that EGFR signaling does not play a pivotal role in insulinoma carcinogenesis and progression.

Our most striking finding was that $92 \%$ of insulinomas stained moderately to strongly positive for the IGF2 protein, which implicates autocrine activation of the IGF pathway in tumorigenesis, also reported by others (Samani et al.
2007, Weroha \& Haluska 2012, Denduluri et al. 2015). This corresponded well with the 12.4 fold higher IGF2 mRNA level in insulinomas compared to normal pancreatic islets. IGF2 is an imprinted gene, expressed primarily from the paternal allele. Methylation of the IGF2 regulatory regions has been reported in many cancers, resulting in loss of 
A
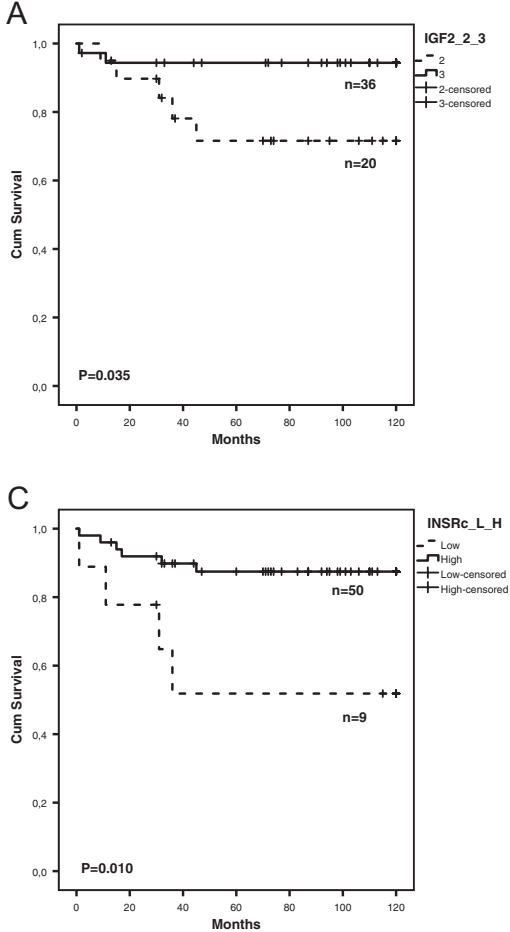

E

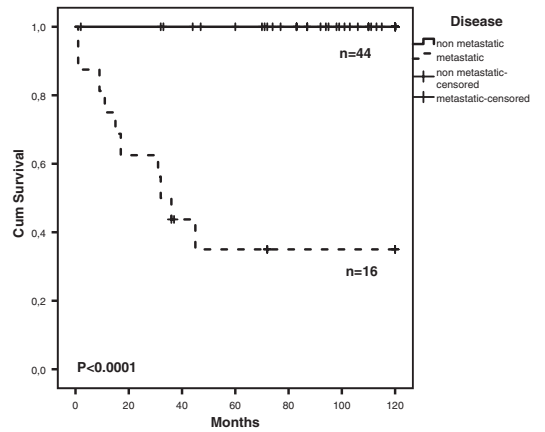

G

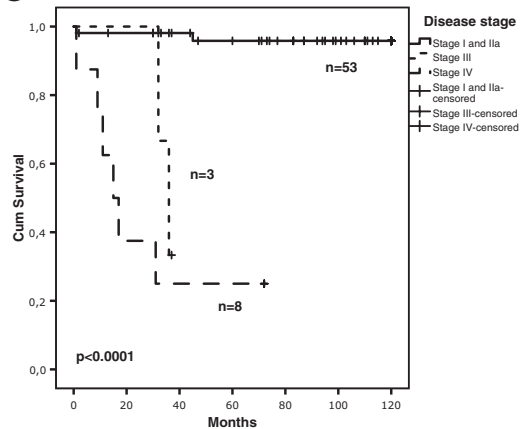

B

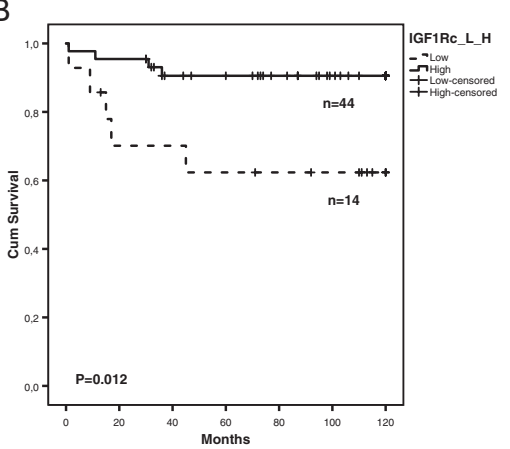

D

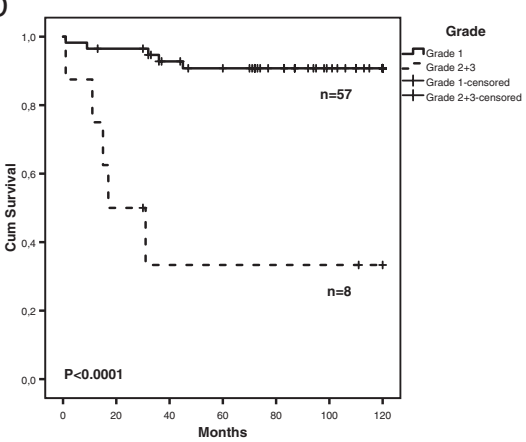

$\mathrm{F}$

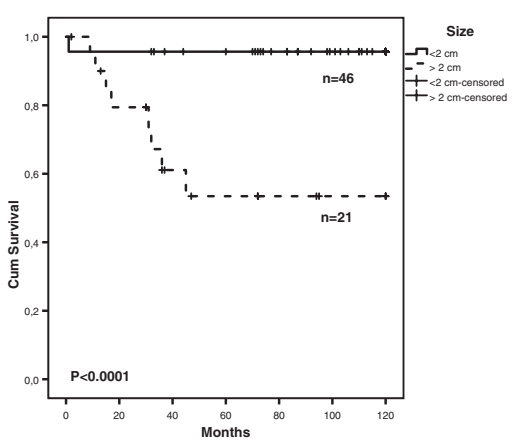

Figure 4

Kaplan-Meier analysis showing 10-year disease-free survival rates of insulinoma patients with regard to protein expression ( $A, B$ and $C$ ) and clinicopathological parameters $(D, E, F$ and $G)$. Correlation between survival and protein expression, (A) IGF2 (moderate (2) vs high (3) expression), (B) cytoplasmic IGF1R (low vs high expression), (C) cytoplasmic INSR (low vs high expression), (D) Grade (Grade1 vs Grade 2+3), (E) Disease (non-metastatic vs metastatic), (F) Tumor size $(<2 \mathrm{~cm}$ vs $\geq 2 \mathrm{~cm})$ and $(\mathrm{G})$ Disease stage. imprinting and protein overexpression (Murphy et al. 2006, Cerrato et al. 2008, Dejeux et al. 2009, Livingstone 2013, Creemers et al. 2016). Dejeux et al. (2009) reported hypermethylation of the differentially methylated region 2 (DMR2) as a specific event in insulinomas, leading, in a subset of the samples, to IGF2 mRNA overexpression compared to normal pancreatic tissue, other PanNETs (gastrinomas and non-functioning) and small intestinal endocrine tumors. At the protein level, they found moderate to high expression levels in 14/28 insulinomas. The use of a different primary antibody and unspecified immunostaining procedure might explain the lower 
Table 5 Significance levels ( $P$-values) for univariate analysis of insulinomas, indicating the relation of clinical and molecular parameters with disease outcome for tumors subjected to (A) mRNA expression analysis and (B) protein expression analysis.

\begin{tabular}{|c|c|c|}
\hline \multirow[b]{2}{*}{ A } & \multicolumn{2}{|c|}{$P$-value } \\
\hline & OS & DFS \\
\hline Gradea & 0.007 & 0.002 \\
\hline Disease $^{b}$ & $<0.0001$ & $<0.0001$ \\
\hline Tumor sizec & 0.003 & $<0.0001$ \\
\hline Disease staged $^{d}$ & $<0.0001$ & $<0.0001$ \\
\hline$I N S e$ & $<0.0001 \mathrm{~g}$ & $<0.0001 \mathrm{~g}$ \\
\hline$I G F 1 R^{\mathrm{e}}$ & $<0.0001 \mathrm{~g}$ & $<0.00019$ \\
\hline$I N S R-A^{\mathrm{e}}$ & $0.032 \mathrm{~g}$ & $0.0019 \mathrm{~g}$ \\
\hline IGFBPЗе & $0.001^{h}$ & $<0.0001^{h}$ \\
\hline
\end{tabular}

\begin{tabular}{l} 
B \\
\hline Gradea $^{\text {Disease }}$ \\
Tumor sizec $^{\mathrm{C}}$ \\
Disease stage $^{\mathrm{d}}$ \\
IGF2 $^{\mathrm{f}}$ \\
IGF1R $^{f}$ \\
INSR $^{f}$
\end{tabular}

\begin{tabular}{ccc}
\multicolumn{2}{c}{$\boldsymbol{P}$-value } \\
\cline { 1 - 1 } OS & \multicolumn{1}{c}{ DFS } \\
\hline$<0.0001$ & & $<0.0001$ \\
$<0.0001$ & & $<0.0001$ \\
$<0.0001$ & & $<0.0001$ \\
$<0.0001$ & & $<0.0001$ \\
0.0279 & & 0.0359 \\
0.0339 & & $0.012 \mathrm{~g}$ \\
0.0169 & & 0.0109
\end{tabular}

aGrade 1 vs Grade 2+3; bnon-metastatic vs metastatic disease; ctumor size $<2 \mathrm{~cm}$ vs $\geq 2 \mathrm{~cm}$; disease stage I+II vs IV; ehigh vs low mRNA expression (Fig. $2 \mathrm{~A}$ $\mathrm{B}, \mathrm{C}$ and $\mathrm{D}$ legend); fhigh vs low protein expression (Fig. $3 \mathrm{~A}, \mathrm{~B}$ and $\mathrm{C}$ legend); $\mathrm{g} P$-values refer to shorter 10 years survival for lower expression; $\mathrm{h} P$-values refer to shorter 10-years survival for higher expression. DFS, disease-free survival; OS, overall survival.

frequency of IGF2 positive insulinomas. (Hoog et al. 2001) detected higher levels of IGF2 protein in 16 out of 18 insulinomas, which is in accordance with our findings. In contrast to IGF2, the mRNA expression of IGF1 was very low in insulinomas and not detectable in normal pancreatic islets.

The IGF signaling pathway is activated by binding of the ligands IGF1, IGF2 or insulin to their respective receptors, IGF1R and INSR. Posttranscriptional alternative splicing of INSR results in two isoforms, INSR-A (which lacks exon 11) and INSR-B. IGF2 binds with similar affinity both to IGF1R and INSR-A, which promotes cell growth, proliferation and survival (Chao \& D'Amore 2008). IGF1R and INSR are overexpressed in a variety of cancers, including breast, prostate, osteosarcoma and thyroid carcinomas (Lodhia et al. 2015). In our study, we found moderate-to-strong cytoplasmic and membranous IGF1R and cytoplasmic INSR protein expression in 51, 78 and $83 \%$ of the insulinomas, respectively, which was at least similar, or stronger in staining intensity than observed in pancreatic islets. Since we found a correlation between IGF1R and high IGF2 protein expression levels, these data suggest the presence of an autocrine proliferative loop in insulinomas, as described for other cancer types (Bergman et al. 2013, Livingstone 2013).

Binding of IGF1 or IGF2 to IGF1R or INSR leads to autophosphorylation of the $\beta$ subunit tyrosine kinase and recruitment of INSR substrates (IRS), inducing activation of the MAPK/ERK and PI3K/AKT signaling pathways (Alvino et al. 2011). Phosphorylation of AKT leads to activation of mTOR and downstream effectors of mTORC1 S6K and 4EBP1, both regulators of mRNA translation and involved in cell proliferation and survival (Robbins \& Hague 2015). Although 51 and 83\% respectively, of the insulinomas in our study express IGF1R and INSR protein, only $22 \%$ and 32\% respectively, strongly express nuclear p-AKT and p-ERK, and 4 and 19\% respectively, express p-S6K and p-4EBP1. Interestingly, a positive correlation was found between cytoplasmic IGF1R expression on the one hand and IGF2 and nuclear p-ERK on the other. Also at the mRNA level a correlation was observed between $A K T, E R K 1, R P S 6 K B 1$ and MTOR. The fact that IGF1R signaling does not necessarily results in AKT/ mTOR signaling might be the result of an intact PTEN expression in about two third of the tumors, inhibiting PI3K and subsequent downstream signaling. Reduced PTEN expression or altered subcellular localization has been reported to activate $\mathrm{PI} 3 \mathrm{~K} / \mathrm{AKT} / \mathrm{mTOR}$ signaling in PanNETs (Perren et al. 2000, Missiaglia et al. 2010), which might have occurred in the remaining one third of the insulinomas in our study. In a pilot study of ten cases, we indeed observed altered subcellular localisation of PTEN expression, as compared to normal islets, in four cases with p-AKT and p-S6K expression (Data not shown). (Komori et al. 2014) also found active mTOR signaling in $22-35 \%$ of a group of 14 insulinomas tested for among others p-mTOR, p-S6K and p-4EBP1. The percentage of tumors exhibiting active AKT/mTOR signaling varies significantly in different studies due to different PanNET subgroups tested, as well as different antibodies and cut-off criteria for positivity used (Ghayouri et al. 2010, Kasajima et al. 2011, Qian et al. 2013). It is tempting to speculate that $\mathrm{p}-\mathrm{AKT}$ and/or $\mathrm{p}-\mathrm{S} 6 \mathrm{~K}$ are putative predictive markers of response to everolimus. A recent study on PanNETs indeed showed anecdotal evidence of p-AKT for this role in a primary cell culture model for response to everolimus (Falletta et al. 2016).

We observed a decreased level of several IGF pathway components in relation to tumor grade, metastatic disease, tumor size and disease stage. The protein expression levels 
of IGF2, cytoplasmic IGF1R, cytoplasmic and membranous INSR and cytoplasmic p-S6K were significantly lower in tumors from patients with metastatic disease than from those with non-metastatic disease. Also the mean mRNA expression levels of INS were significantly lower in patients with metastatic insulinomas as compared to non-metastatic insulinomas. This finding is furthermore reflected in the lower levels of these IGF pathway proteins and their mRNAs in association with shorter 10-year disease-free survival and overall rates. A decrease in both IGF1R protein and gene expression levels has been described before in esophageal adenocarcinoma, colorectal and breast cancer (Schnarr et al. 2000, Allison et al. 2007, Kuklinski et al. 2011, De Bruijn et al. 2015) and might reflect a dedifferentiation process. Indeed, two recent genomic studies have identified distinctive $\mathrm{m}(\mathrm{i})$ RNA expression profiles, separating PanNET with liver metastases (metastasis like primary tumor subtype) from well-differentiated PanNETs (well-differentiated islet/insulinoma tumor subtype), further underscoring dedifferentiation to be reflected in gene expression signatures (Sadanandam et al. 2015, Scarpa et al. 2017). Decreased insulin signaling was one described hallmark of mouse metastasis like primary PanNET (Sadanandam et al. 2015). It remains to be studied whether the changes in gene expression seen in insulinomas reflect a different entity or are the result of tumor progression.

An interesting finding was that the shorter 10-year overall and disease-free survival rates also correlated with higher levels of IGFBP3 mRNA in insulinomas. This gene belongs to a family of 6 IGF-binding proteins, which function as transport proteins for IGF1 and IGF2 in the peripheral circulation, and in this way, limit the bioavailability of IGFs, as well as modulators of cell function via among others IGF1R-dependent mechanisms (Baxter 2014). IGFBP3 has been proposed to function as either tumor promoter or suppressor (Baxter 2014). On the one hand, overexpression is detected in association with tumor progression in many tumor types, such as head and neck carcinoma (Marimuthu et al. 2013), melanoma (Xi et al. 2006) or renal clear cell carcinoma (Takahash et al. 2005), and on the other hand, Ren et al. (2007) found a higher IGFBP3 mRNA expression in benign as compared to malignant breast tumors. In agreement with our study, Hansel et al. (2004) found higher expression levels of IGFBP3 in well-differentiated PanNETs of patients with metastatic disease, although this particularly comprised non-functioning tumors and no metastatic insulinomas were included. A high IGFBP3 mRNA expression was also identified in PanNETs of the metastasis like primary
PanNET subtype in a recent genomic analysis (Scarpa et al. 2017).

In conclusion, our observations suggest that insulinomas are characterized by high expression levels of IGF signaling pathway components, with a possibility of a strong autocrine loop especially in benign welldifferentiated insulinomas. This IGF signaling pathway appears to be downregulated during tumor progression, coinciding with a shorter 10-year disease-free survival.

\section{Supplementary data}

This is linked to the online version of the paper at https://doi.org/10.1530/ ERC-18-0222.

Declaration of interest

The authors declare that there is no conflict of interest that could be perceived as prejudicing the impartiality of the research reported.

\section{Funding}

This study was supported by The Dutch Digestion Foundation (MLDS, WO06-25) (to E-J M S). A A Perren was supported by Swiss Cancer League (KFS 3360-02-2014) and SNF (310030-144236).

\section{Acknowledgements}

The authors thank Prof. Dr A Driessen for her support in classification of the NETS, Dr M Gielen and Dr J Derks for advice regarding statistical evaluation of the data, Prof. Dr P E Goretzki for providing tissue samples and F Dogan for technical assistance with part of the qRT-PCR assays.

\section{References}

Allison AS, McIntyre MA, McArdle C \& Habib FK 2007 The insulin-like growth factor type 1 receptor and colorectal neoplasia: insights into invasion. Human Pathology 38 1590-1602. (https://doi.org/10.1016/j. humpath.2007.03.013)

Alvino CL, Ong SC, McNeil KA, Delaine C, Booker GW, Wallace JC \& Forbes BE 2011 Understanding the mechanism of insulin and insulin-like growth factor (IGF) receptor activation by IGF-II. PLoS ONE 6 e27488. (https://doi.org/10.1371/journal.pone.0027488)

Baxter RC 2014 IGF binding proteins in cancer: mechanistic and clinical insights. Nature Reviews Cancer 14 329-341. (https://doi.org/10.1038/ nrc3720)

Bergman D, Halje M, Nordin M \& Engstrom W 2013 Insulin-like growth factor 2 in development and disease: a mini-review. Gerontology 59 240-249. (https://doi.org/10.1159/000343995)

Bergmann F, Breinig M, Hopfner M, Rieker RJ, Fischer L, Kohler C, Esposito I, Kleeff J, Herpel E, Ehemann V, et al. 2009 Expression pattern and functional relevance of epidermal growth factor receptor and cyclooxygenase-2: novel chemotherapeutic targets in pancreatic endocrine tumors? American Journal of Gastroenterology 104 171-181. (https://doi.org/10.1038/ajg.2008.33)

Cao Y, Gao Z, Li L, Jiang X, Shan A, Cai J, Peng Y, Li Y, Jiang X, Huang X, et al. 2013 Whole exome sequencing of insulinoma reveals recurrent T372R mutations in YY1. Nature Communications 42810. (https://doi.org/10.1038/ncomms3810)
(2) 2018 Society for Endocrinology Published by Bioscientifica Ltd. Printed in Great Britain 
Cerrato F, Sparago A, Verde G, De Crescenzo A, Citro V, Cubellis MV, Rinaldi MM, Boccuto L, Neri G, Magnani C, et al. 2008 Different mechanisms cause imprinting defects at the IGF2/H19 locus in Beckwith-Wiedemann syndrome and Wilms' tumour. Human Molecular Genetics 17 1427-1435. (https://doi.org/10.1093/hmg/ ddn031)

Chao W \& D'Amore PA 2008 IGF2: epigenetic regulation and role in development and disease. Cytokine and Growth Factor Reviews 19 111-120. (https://doi.org/10.1016/j.cytogfr.2008.01.005)

Ciardiello F \& Tortora G 2008 EGFR antagonists in cancer treatment. New England Journal of Medicine 358 1160-1174. (https://doi. org/10.1056/NEJMra0707704)

Cives M, Soares HP \& Strosberg J 2016 Will clinical heterogeneity of neuroendocrine tumors impact their management in the future? Lessons from recent trials. Current Opinion in Oncology 28 359-366. (https://doi.org/10.1097/CCO.0000000000000299)

Creemers SG, van Koetsveld PM, van Kemenade FJ, Papathomas TG, Franssen GJ, Dogan F, Eekhoff EM, van der Valk P, de Herder WW, Janssen JA, et al. 2016 Methylation of IGF2 regulatory regions to diagnose adrenocortical carcinomas. Endocrine-Related Cancer 23 727-737. (https://doi.org/10.1530/ERC-16-0266)

Dasari A, Shen C, Halperin D, Zhao B, Zhou S, Xu Y, Shih T \& Yao JC 2017 Trends in the incidence, prevalence, and survival outcomes in patients with neuroendocrine tumors in the United States. JAMA Oncology 3 1335-1342. (https://doi.org/10.1001/ jamaoncol.2017.0589)

De Bruijn K, Biermann K, Shapiro J, Dogan F, Spaander M, Janssen J, Wijnhoven B, Borsboom G, Hofland L \& van Eijck C 2015 Absence or low IGF-1R-expression in esophageal adenocarcinoma is associated with tumor invasiveness and radicality of surgical resection. Journal of Surgical Oncology 111 1047-1053. (https://doi. org/10.1002/jso.23923)

Dejeux E, Olaso R, Dousset B, Audebourg A, Gut IG, Terris B \& Tost J 2009 Hypermethylation of the IGF2 differentially methylated region 2 is a specific event in insulinomas leading to loss-of-imprinting and overexpression. Endocrine-Related Cancer 16 939-952. (https://doi. org/10.1677/ERC-08-0331)

Denduluri SK, Idowu O, Wang Z, Liao Z, Yan Z, Mohammed MK, Ye J, Wei Q, Wang J, Zhao L, et al. 2015 Insulin-like growth factor (IGF) signaling in tumorigenesis and the development of cancer drug resistance. Genes and Diseases 2 13-25. (https://doi.org/10.1016/j. gendis.2014.10.004)

Falletta S, Partelli S, Rubini C, Nann D, Doria A, Marinoni I, Polenta V, Di Pasquale C, Degli Uberti E, Perren A, et al. 2016 mTOR inhibitors response and mTOR pathway in pancreatic neuroendocrine tumors. Endocrine-Related Cancer 23 883-891. (https://doi.org/10.1530/ERC16-0329)

Fjallskog ML, Lejonklou MH, Oberg KE, Eriksson BK \& Janson ET 2003 Expression of molecular targets for tyrosine kinase receptor antagonists in malignant endocrine pancreatic tumors. Clinical Cancer Research 9 1469-1473.

Garraway LA \& Janne PA 2012 Circumventing cancer drug resistance in the era of personalized medicine. Cancer Discovery 2 214-226. (https://doi.org/10.1158/2159-8290.CD-12-0012)

Gentzler RD, Altman JK \& Platanias LC 2012 An overview of the mTOR pathway as a target in cancer therapy. Expert Opinion on Therapeutic Targets 16 481-489. (https://doi.org/10.1517/14728222.2012.677439)

Ghayouri M, Boulware D, Nasir A, Strosberg J, Kvols L \& Coppola D 2010 Activation of the serine/theronine protein kinase Akt in enteropancreatic neuroendocrine tumors. Anticancer Research 30 5063-5067.

Gilbert JA, Adhikari LJ, Lloyd RV, Halfdanarson TR, Muders MH \& Ames MM 2013 Molecular markers for novel therapeutic strategies in pancreatic endocrine tumors. Pancreas 42 411-421. (https://doi. org/10.1097/MPA.0b013e31826cb243)
Hansel DE, Rahman A, House M, Ashfaq R, Berg K, Yeo CJ \& Maitra A 2004 Met proto-oncogene and insulin-like growth factor binding protein 3 overexpression correlates with metastatic ability in welldifferentiated pancreatic endocrine neoplasms. Clinical Cancer Research 10 6152-6158. (https://doi.org/10.1158/1078-0432.CCR-040285)

Hobday TJ, Holen K, Donehower R, Camoriano J, Kim G, Picus J, Philip P, Lloyd R, Mahoney M \& Erlichman C 2006 A phase II trial of gefitinib in patients (pts) with progressive metastatic neuroendocrine tumors (NET): A Phase II Consortium (P2C) study. ASCO Meeting Abstracts 244043.

Hoog A, Kjellman M, Nordqvist AC, Hoog CM, Juhlin C, Falkmer S, Schalling M \& Grimelius L 2001 Insulin-like growth factor-II in endocrine pancreatic tumours. Immunohistochemical, biochemical and in situ hybridization findings. APMIS 109 127-40. (https://doi. org/10.1034/j.1600-0463.2001.d01-114.x)

Jiao Y, Shi C, Edil BH, de Wilde RF, Klimstra DS, Maitra A, Schulick RD, Tang LH, Wolfgang CL, Choti MA, et al. 2011 DAXX/ATRX, MEN1, and mTOR pathway genes are frequently altered in pancreatic neuroendocrine tumors. Science 331 1199-1203. (https://doi. org/10.1126/science.1200609)

Jonkers YM, Claessen SM, Perren A, Schmitt AM, Hofland LJ, de Herder W, de Krijger RR, Verhofstad AA, Hermus AR, Kummer JA, et al. 2007 DNA copy number status is a powerful predictor of poor survival in endocrine pancreatic tumor patients. Endocrine-Related Cancer 14 769-779. (https://doi.org/10.1677/ERC-07-0111)

Kasajima A, Pavel M, Darb-Esfahani S, Noske A, Stenzinger A, Sasano H Dietel M, Denkert C, Rocken C, Wiedenmann B, et al. 2011 mTOR expression and activity patterns in gastroenteropancreatic neuroendocrine tumours. Endocrine-Related Cancer 18 181-192. (https://doi.org/10.1677/ERC-10-0126)

Komori Y, Yada K, Ohta M, Uchida H, Iwashita Y, Fukuzawa K, Kashima K, Yokoyama S, Inomata M \& Kitano S 2014 Mammalian target of rapamycin signaling activation patterns in pancreatic neuroendocrine tumors. Journal of Hepato-Biliary-Pancreatic Sciences 21 288-295. (https://doi.org/10.1002/jhbp.26)

Kuklinski A, Kamocki Z, Koda M, Piotrowski Z, Sulkowski S, Lesniewicz R, Pawlak K, Mysliwiec P \& Kedra B 2011 IGF-IR in patients with advanced colorectal cancer in correlation with certain clinico-morphological factors: initial report. Oncology Letters 2 1155-1159. (https://doi.org/10.3892/ol.2011.396)

Livingstone C 2013 IGF2 and cancer. Endocrine-Related Cancer 20 R321-R339. (https://doi.org/10.1530/ERC-13-0231)

Lodhia KA, Tienchaiananda P \& Haluska P 2015 Understanding the key to targeting the IGF axis in cancer: a biomarker assessment. Frontiers in Oncology 5 142. (https://doi.org/10.3389/fonc.2015.00142)

Ludovini V, Bellezza G, Pistola L, Bianconi F, Di Carlo L, Sidoni A, Semeraro A, Del Sordo R, Tofanetti FR, Mameli MG, et al. 2009 High coexpression of both insulin-like growth factor receptor-1 (IGFR-1) and epidermal growth factor receptor (EGFR) is associated with shorter disease-free survival in resected non-small-cell lung cancer patients. Annals of Oncology 20 842-849. (https://doi.org/10.1093/ annonc/mdn727)

Marimuthu A, Chavan S, Sathe G, Sahasrabuddhe NA, Srikanth SM, Renuse S, Ahmad S, Radhakrishnan A, Barbhuiya MA, Kumar RV, et al. 2013 Identification of head and neck squamous cell carcinoma biomarker candidates through proteomic analysis of cancer cell secretome. Biochimica et Biophysica Acta 1834 2308-2316. (https:// doi.org/10.1016/j.bbapap.2013.04.029)

Marinoni I, Kurrer AS, Vassella E, Dettmer M, Rudolph T, Banz V, Hunger F, Pasquinelli S, Speel EJ \& Perren A 2014 Loss of DAXX and ATRX are associated with chromosome instability and reduced survival of patients with pancreatic neuroendocrine tumors. Gastroenterology 146 453.e455-460.e455. (https://doi.org/10.1053/j. gastro.2013.10.020) (c) 2018 Society for Endocrinology Published by Bioscientifica Ltd. Printed in Great Britain 
Missiaglia E, Dalai I, Barbi S, Beghelli S, Falconi M, della Peruta M, Piemonti L, Capurso G, Di Florio A, delle Fave G, et al. 2010 Pancreatic endocrine tumors: expression profiling evidences a role for AKT-mTOR pathway. Journal of Clinical Oncology 28 245-255. (https://doi.org/10.1200/JCO.2008.21.5988)

Muniraj T, Vignesh S, Shetty S, Thiruvengadam S \& Aslanian HR 2013 Pancreatic neuroendocrine tumors. Disease-a-month 59 5-19. (https://doi.org/10.1016/j.disamonth.2012.10.002)

Murphy SK, Huang Z, Wen Y, Spillman MA, Whitaker RS, Simel LR, Nichols TD, Marks JR \& Berchuck A 2006 Frequent IGF2/H19 domain epigenetic alterations and elevated IGF2 expression in epithelial ovarian cancer. Molecular Cancer Research 4 283-292. (https://doi.org/10.1158/1541-7786.MCR-05-0138)

Oberg K 2012 Neuroendocrine tumors of the digestive tract: impact of new classifications and new agents on therapeutic approaches. Current Opinion in Oncology 24 433-440. (https://doi.org/10.1097/ CCO.0b013e328353d7ba)

Papouchado B, Erickson LA, Rohlinger AL, Hobday TJ, Erlichman C, Ames MM \& Lloyd RV 2005 Epidermal growth factor receptor and activated epidermal growth factor receptor expression in gastrointestinal carcinoids and pancreatic endocrine carcinomas. Modern Pathology 18 1329-1335. (https://doi.org/10.1038/ modpathol.3800427)

Perren A, Komminoth P, Saremaslani P, Matter C, Feurer S, Lees JA, Heitz PU \& Eng C 2000 Mutation and expression analyses reveal differential subcellular compartmentalization of PTEN in endocrine pancreatic tumors compared to normal islet cells. American Journal of Pathology 157 1097-1103. (https://doi.org/10.1016/S00029440(10)64624-X)

Qian ZR, Ter-Minassian M, Chan JA, Imamura Y, Hooshmand SM, Kuchiba A, Morikawa T, Brais LK, Daskalova A, Heafield R, et al. 2013 Prognostic significance of MTOR pathway component expression in neuroendocrine tumors. Journal of Clinical Oncology 31 3418-3425. (https://doi.org/10.1200/JCO.2012.46.6946)

Rajapaksha H \& Forbes BE 2015 Ligand-binding affinity at the insulin receptor isoform-A and subsequent IR-A tyrosine phosphorylation kinetics are important determinants of mitogenic biological outcomes. Frontiers in Endocrinology 6107.

Ren Z, Shin A, Cai Q, Shu XO, Gao YT \& Zheng W 2007 IGFBP3 mRNA expression in benign and malignant breast tumors. Breast Cancer Research 9 R2. (https://doi.org/10.1186/bcr1634)

Robbins HL \& Hague A 2015 The PI3K/Akt pathway in tumors of endocrine tissues. Frontiers in Endocrinology 6188.

Sadanandam A, Wullschleger S, Lyssiotis CA, Grotzinger C, Barbi S, Bersani S, Korner J, Wafy I, Mafficini A, Lawlor RT et al. 2015 A cross-species analysis in pancreatic neuroendocrine tumors reveals molecular subtypes with distinctive clinical, metastatic, developmental, and metabolic characteristics. Cancer Discovery 5 1296-1313. (https://doi.org/10.1158/2159-8290.CD-15-0068)

Samani AA, Yakar S, LeRoith D \& Brodt P 2007 The role of the IGF system in cancer growth and metastasis: overview and recent insights. Endocrine Reviews 28 20-47. (https://doi.org/10.1210/ er.2006-0001)

Scarpa A, Chang DK, Nones K, Corbo V, Patch AM, Bailey P, Lawlor RT, Johns AL, Miller DK, Mafficini A, et al. 2017 Whole-genome landscape of pancreatic neuroendocrine tumours. Nature 543 65-71. (https://doi.org/10.1038/nature21063)

Schnarr B, Strunz K, Ohsam J, Benner A, Wacker J \& Mayer D 2000 Down-regulation of insulin-like growth factor-I receptor and insulin receptor substrate-1 expression in advanced human breast cancer. International Journal of Cancer 89 506-513. (https://doi. org/10.1002/1097-0215(20001120)89:6<506::AID-IJC7>3.0.CO;2-F)

Srivastava A, Alexander J, Lomakin I \& Dayal Y 2001 Immunohistochemical expression of transforming growth factor alpha and epidermal growth factor receptor in pancreatic endocrine tumors. Human Pathology 32 1184-1189. (https://doi.org/10.1053/ hupa.2001.28959)

Takahash M, Papavero V, Yuhas J, Kort E, Kanayama HO, Kagawa S, Baxter RC, Yang XMJ, Gray SG \& Teh BT 2005 Altered expression of members of the IGF-axis in clear cell renal cell carcinoma. International Journal of Oncology 26 923-931.

Weroha SJ \& Haluska P 2012 The insulin-like growth factor system in cancer. Endocrinology Metabolism Clinics of North America 41 335-350. (https://doi.org/10.1016/j.ecl.2012.04.014)

Wulbrand U, Wied M, Zofel P, Goke B, Arnold R \& Fehmann H 1998 Growth factor receptor expression in human gastroenteropancreatic neuroendocrine tumours. European Journal of Clinical Investigation $\mathbf{2 8}$ 1038-1049. (https://doi.org/10.1046/j.1365-2362.1998.00397.x)

Wulbrand U, Remmert G, Zofel P, Wied M, Arnold R \& Fehmann HC 2000 mRNA expression patterns of insulin-like growth factor system components in human neuroendocrine tumours. European Journal of Clinical Investigation 30 729-739. (https://doi. org/10.1046/j.1365-2362.2000.00700.x)

Xi Y, Nakajima G, Hamil T, Fodstad O, Riker A \& Ju J 2006 Association of insulin-like growth factor binding protein-3 expression with melanoma progression. Molecular Cancer Therapeutics 5 3078-3084. (https://doi.org/10.1158/1535-7163.MCT-06-0424)

Yao JC, Shah MH, Ito T, Bohas CL, Wolin EM, Van Cutsem E, Hobday TJ, Okusaka T, Capdevila J, de Vries EG, et al. 2011 Everolimus for advanced pancreatic neuroendocrine tumors. New England Journal of Medicine 364 514-523. (https://doi.org/10.1056/ NEJMoa1009290)

Yao JC, Fazio N, Singh S, Buzzoni R, Carnaghi C, Wolin E, Tomasek J, Raderer M, Lahner H, Voi M, et al. 2016 Everolimus for the treatment of advanced, non-functional neuroendocrine tumours of the lung or gastrointestinal tract (RADIANT-4): a randomised, placebo-controlled, phase 3 study. Lancet 387 968-977. (https://doi. org/10.1016/S0140-6736(15)00817-X)

Zhan HX, Cong L, Zhao YP, Zhang TP, Chen G, Zhou L \& Guo JC 2012 Activated mTOR/P70S6K signaling pathway is involved in insulinoma tumorigenesis. Journal of Surgical Oncology 106 972-980. (https://doi.org/10.1002/jso.23176)

Received in final form 28 June 2018

Accepted 16 July 2018

Accepted Preprint published online 18 July 2018 (c) 2018 Society for Endocrinology Published by Bioscientifica Ltd. Printed in Great Britain 